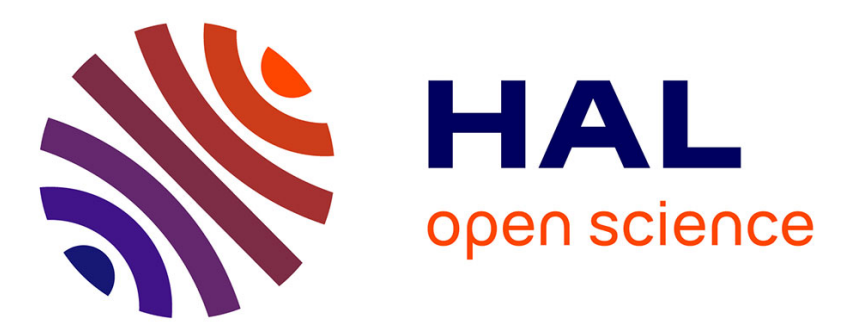

\title{
Modeling fire and the terrestrial carbon balance
}

I. Prentice, D. Kelley, P. Foster, P. Friedlingstein, S. Harrison, P. Bartlein

\section{To cite this version:}

I. Prentice, D. Kelley, P. Foster, P. Friedlingstein, S. Harrison, et al.. Modeling fire and the terrestrial carbon balance. Global Biogeochemical Cycles, 2011, 25 (3), pp.n/a-n/a. 10.1029/2010GB003906 . hal-03203083

\section{HAL Id: hal-03203083 \\ https://hal.science/hal-03203083}

Submitted on 22 Apr 2021

HAL is a multi-disciplinary open access archive for the deposit and dissemination of scientific research documents, whether they are published or not. The documents may come from teaching and research institutions in France or abroad, or from public or private research centers.
L'archive ouverte pluridisciplinaire HAL, est destinée au dépôt et à la diffusion de documents scientifiques de niveau recherche, publiés ou non, émanant des établissements d'enseignement et de recherche français ou étrangers, des laboratoires publics ou privés. 


\title{
Modeling fire and the terrestrial carbon balance
}

\author{
I. C. Prentice, ${ }^{1,2,3}$ D. I. Kelley, ${ }^{2,4}$ P. N. Foster, ${ }^{1}$ P. Friedlingstein, $,{ }^{1,4,5}, 6$ S. P. Harrison,,${ }^{2,4}$ \\ and P. J. Bartlein ${ }^{7}$
}

Received 29 June 2010; revised 15 March 2011; accepted 5 April 2011; published 8 July 2011.

[1] Four $\mathrm{CO}_{2}$ concentration inversions and the Global Fire Emissions Database (GFED)

versions 2.1 and 3 are used to provide benchmarks for climate-driven modeling of the global land-atmosphere $\mathrm{CO}_{2}$ flux and the contribution of wildfire to this flux. The Land surface Processes and exchanges (LPX) model is introduced. LPX is based on the Lund-Potsdam-Jena Spread and Intensity of FIRE (LPJ-SPITFIRE) model with amended fire probability calculations. LPX omits human ignition sources yet simulates many aspects of global fire adequately. It captures the major features of observed geographic pattern in burnt area and its seasonal timing and the unimodal relationship of burnt area to precipitation. It simulates features of geographic variation in the sign of the interannual correlations of burnt area with antecedent dryness and precipitation. It simulates well the interannual variability of the global total land-atmosphere $\mathrm{CO}_{2}$ flux. There are differences among the global burnt area time series from GFED2.1, GFED3 and LPX, but some features are common to all. GFED3 fire $\mathrm{CO}_{2}$ fluxes account for only about $1 / 3$ of the variation in total $\mathrm{CO}_{2}$ flux during 1997-2005. This relationship appears to be dominated by the strong climatic dependence of deforestation fires. The relationship of LPX-modeled fire $\mathrm{CO}_{2}$ fluxes to total $\mathrm{CO}_{2}$ fluxes is weak. Observed and modeled total $\mathrm{CO}_{2}$ fluxes track the El Niño-Southern Oscillation (ENSO) closely; GFED3 burnt area and global fire $\mathrm{CO}_{2}$ flux track the ENSO much less so. The GFED3 fire $\mathrm{CO}_{2}$ flux-ENSO connection is most prominent for the El Niño of 1997-1998, which produced exceptional burning conditions in several regions, especially equatorial Asia. The sign of the observed relationship between ENSO and fire varies regionally, and LPX captures the broad features of this variation. These complexities underscore the need for process-based modeling to assess the consequences of global change for fire and its implications for the carbon cycle.

Citation: Prentice, I. C., D. I. Kelley, P. N. Foster, P. Friedlingstein, S. P. Harrison, and P. J. Bartlein (2011), Modeling fire and the terrestrial carbon balance, Global Biogeochem. Cycles, 25, GB3005, doi:10.1029/2010GB003906.

\section{Introduction}

[2] Fire is a fundamental Earth System process that is incompletely understood, involves both vegetation and climatic processes, and challenges current observational and modeling capabilities [Bowman et al., 2009]. The dependence

\footnotetext{
${ }^{1}$ QUEST, Department of Earth Sciences, University of Bristol, Bristol, UK.

${ }^{2}$ Department of Biological Sciences, Macquarie University, North Ryde, New South Wales, Australia.

${ }^{3}$ Grantham Institute for Climate Change, and Division of Biology, Imperial College, Ascot, UK.

${ }^{4}$ School of Geographical Sciences, University of Bristol, Bristol, UK.

${ }^{5}$ Laboratoire des Sciences du Climat et de l'Environnement, CNRS, CEA, UVSQ, Gif-Sur-Yvette, France.

${ }^{6}$ Department of Engineering, Computing and Mathematics, University of Exeter, Exeter, UK. USA.

Department of Geography, University of Oregon, Eugene, Oregon,

Copyright 2011 by the American Geophysical Union. 0886-6236/11/2010GB003906
}

of fire on climate is a particular concern, given global warming and the threat already posed by large, uncontrollable fires to human health, property and life [Running, 2006; Bowman et al., 2009]. Increasing temperature is likely to increase the frequency and severity of wildfires in some regions, although precipitation increases may compensate in others; while in some regions, wildfire regimes may be exacerbated by drought [Kurz and Apps, 1999; Scholze et al., 2006; Krawchuk et al., 2009; Pechony and Shindell, 2010; Harrison et al., 2010]. Fire is also potentially important as a feedback in the climate system [Bowman et al., 2009]. If climate change globally favors more intense fire regimes, this would result in a net transfer of carbon from ecosystems to the atmosphere, contributing to positive climate-carbon cycle feedback [Cox et al., 2000; Friedlingstein et al., 2006].

[3] Quantitative analysis of fire-vegetation-climate interactions has been held back until recently by a lack of consistent global data sets on fire, and by the underdeveloped state of global fire modeling [Bowman et al., 2009]. Here we exploit the existence of a global source of quantitative burnt 
area data based on the remote sensing of fires [Giglio et al., 2010], and we build on the development of a process-based model for fire-vegetation interactions in a dynamic global vegetation model (DGVM) [Thonicke et al., 2010] that employs the Rothermel fire spread equations, widely used in operational fire modeling. We show that a fire-enabled DGVM can simulate many aspects of contemporary fire regimes, their seasonality and their relation to environment. We then use data and modeling together to analyze the variability of fire and its implications for the terrestrial carbon balance.

[4] It has been proposed [Langenfelds et al., 2002; Randerson et al., 2005; Patra et al., 2005; Nevison et al., 2008] that a large fraction of the interannual variability in the atmospheric growth rate of $\mathrm{CO}_{2}$ is linked to biomass burning. We revisit this proposal, noting first that the evidence for it is limited. Langenfelds et al. [2002] based their conclusion on a 1992-1999 time series of atmospheric concentration measurements which showed correlation among the interannual variabilities of the growth rate of $\mathrm{CO}_{2}$, the $\delta^{13} \mathrm{C}_{\text {of }} \mathrm{CO}_{2}$, and concentrations of $\mathrm{CO}, \mathrm{H}_{2}$ and $\mathrm{CH}_{4}$. Bousquet et al. [2006] also attributed a component of interannual variability in $\mathrm{CH}_{4}$ concentration to biomass burning. However, $\mathrm{CO}$ was considered by Langenfelds et al. [2002] too short lived to provide a useful constraint while it was recognized that variations in $\delta^{13} \mathrm{CO}_{2}$ could also arise from climatically forced variations in net ecosystem production (the balance of terrestrial photosynthesis and respiration). $\mathrm{H}_{2}$ and $\mathrm{CH}_{4}$ both have larger nonpyrogenic sources, which would also be expected to respond to climate independently of fire [Bousquet et al., 2006; Denman et al., 2007]. Patra et al. [2005, paragraph 1] asserted that "Comparison of inversion results with biogeochemical model simulations provide [sic] strong evidence that biomass burning .... constitutes the major component in landatmosphere carbon flux anomalies," but this statement is poorly supported; it appears to depend on the finding that one model lacking prognostic fire (Biome-BGC) underestimated the interannual variability of $\mathrm{CO}_{2}$ flux. There could be alternative explanations.

[5] What is not in doubt is that the El Niño of 1997-1998 caused an additional flux of $\mathrm{CO}_{2}$ and other combustion products into the atmosphere due to unprecedentedly extensive and long-lasting fires in equatorial Asia, augmented by an unusually high level of fire activity in several other regions including Central and South America and parts of the boreal zone. Total land-atmosphere $\mathrm{CO}_{2}$ flux during this period was temporarily increased by as much as $3 \mathrm{Pg} \mathrm{C} \mathrm{yr}^{-1}$ [e.g., Nevison et al., 2008]. Some early maximum estimates would have attributed most or all of this total $\mathrm{CO}_{2}$ flux anomaly to the fires [e.g., Langenfelds et al., 2002; Page et al., 2002]. However, van der Werf et al. [2004] attributed only 2/3 of the anomaly $\left(\approx 2 \mathrm{Pg} \mathrm{C} \mathrm{yr}^{-1}\right)$ to the fires, and more recent estimates by van der Werf et al. [2006, 2008a] attributed

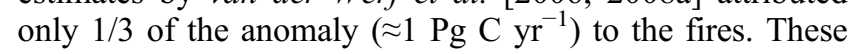
most recent estimates are similar to the minimum estimates of Langenfelds et al. [2002] and Page et al. [2002]. They are also consistent with the analysis of Schimel and Baker [2002] based on the regional $\mathrm{CO}_{2}$ inversion of Gurney et al. [2002]. Randerson et al. [2005], using $\delta^{13} \mathrm{CO}_{2}$ measurements, inferred that tropical $\mathrm{C}_{3}$ vegetation (i.e., forest rather than grassland) was the main source of the additional $\mathrm{CO}_{2}$ released. Here we examine the extent to which inferences based on the years around 1997-1998 are supported, over a longer period beginning in 1997 and extending forward through 2005. This is a period for which there are both timevarying climate data from the Climatic Research Unit (CRU) available to drive a process-based model, and remotely sensed global observations to which model outputs can be compared.

\section{Methods}

\subsection{Data and Models: Overview}

[6] As benchmarks for the space-time patterns of burnt area and fire $\mathrm{CO}_{2}$ emissions, we use monthly data for 1997-2005 derived from the GFED3, the Global Fire Emissions Database version 3 [Giglio et al., 2010; van der Werfet al., 2010; http:// www.falw.vu/ gwerf/GFED/]. GFED3 burnt area is not a "pure" observational product as it depends on empirical modeling of the relationship between burnt area and underlying satellite observations. There are substantial differences among the available burnt area products [see, e.g., Giglio et al., 2010; Kloster et al., 2010], not least between GFED3 and its immediate precursor GFED2.1 [van der Werf et al., 2006; Giglio et al., 2010]. GFED2.1 has been used in several published analyses, most recently by Kloster et al. [2010]. The GFED fire $\mathrm{CO}_{2}$ fluxes, like those simulated by LPX, are obtained via a biogeochemical model that calculates biomass and carbon allocation to different plant tissues, and therefore are one further step removed from observations. Nonetheless, the GFED3 data set represents the most comprehensive attempt to date to derive burnt area and pyrogenic fluxes from remote sensing data, and provides a suitable comparator for model results. GFED3 also includes a first attempt to partition fire $\mathrm{CO}_{2}$ fluxes according to types of fire.

[7] As benchmarks for total land-atmosphere $\mathrm{CO}_{2}$ fluxes we use the three $\mathrm{CO}_{2}$ inversions (based on inversion of atmospheric transport models, guided by space-time patterns of measured $\mathrm{CO}_{2}$ concentrations) [Bousquet et al., 2000; Rödenbeck et al., 2003; Baker et al., 2006] that were presented in the Intergovernmental Panel on Climate Change (IPCC) Fourth Assessment Report [Denman et al., 2007], and the more recent LSCE inversion [Chevallier et al., 2010] which has used a method similar to the method of Bousquet et al. [2000] to extend that analysis forward in time. Although these inversions resolve tropical and extratropical bands, we use only global fluxes, as being the most reliable output of the inversion process. There are potential errors associated with the separation of land and ocean fluxes, but these are relatively unimportant because the interannual variability of the combined land-atmosphere and oceanatmosphere flux is dominated by the land-atmosphere component [Denman et al., 2007].

[8] Modeling provides an independent approach to estimating the fire and total land-atmosphere $\mathrm{CO}_{2}$ fluxes. Fully prognostic modeling of fire and fire-vegetation interactions is a relatively new field, pioneered for DGVMs by Lenihan et al. [1998], Bachelet et al. [2001] and Thonicke et al. [2001], and now pursued by several climate modeling groups [Arora and Boer, 2005; Pechony and Shindell, 2009, 2010; Kloster et al., 2010]. Here we confront a state-of-theart fire-enabled DGVM, the Land surface Processes and exchanges (LPX) model, with tests based on GFED3 and on the analysis of spatial patterns and interannual variability in burnt area as originally presented by van der Werf et al. [2008b]. We test the model's ability to reproduce the 


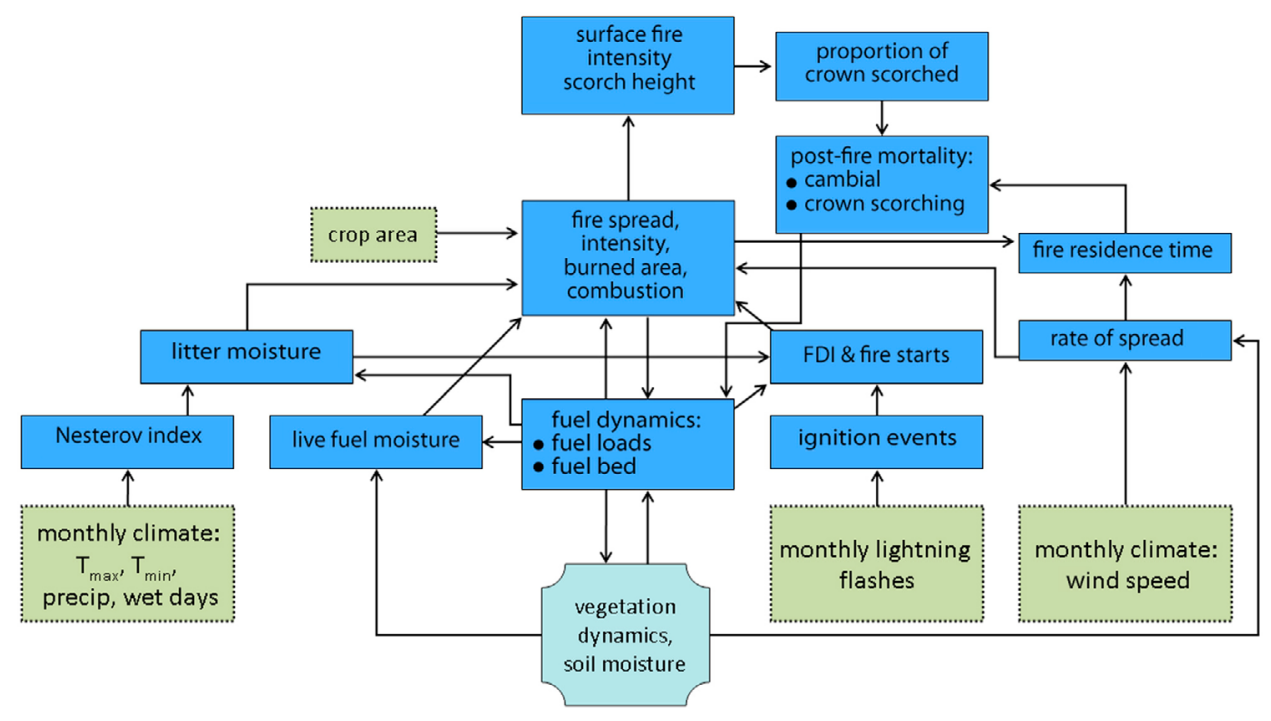

Figure 1. Description of the structure of the fire component of LPX. Inputs to the model are identified by green boxes, outputs from the vegetation dynamics component of model are identified by light blue box, and internal processes and exchanges that are explicitly simulated by the fire component of the model are identified by blue boxes.

main features of interannual variability in the total landatmosphere $\mathrm{CO}_{2}$ flux [cf. McGuire et al., 2001; Peylin et al., 2005] as well as consistent and credible simulations of burnt area and the wildfire $\mathrm{CO}_{2}$ flux.

\subsection{Model Description}

[9] The Land-surface Processes and exchanges (LPX) model is a development from the LPJ Spread and Intensity of FIRE (LPJ-SPITFIRE) model [Thonicke et al., 2010], which in turn is based on the Lund-Potsdam-Jena (LPJ) DGVM [Sitch et al., 2003; Gerten et al., 2004]. LPJ-SPITFIRE represents the influence of potential ignition rates, vegetation properties and weather conditions on biomass burning through explicit formulations of the probability of fires starting, their rate of spread, the amount of fuel combusted, and consequences for the mortality and regeneration of different plant functional types (PFTs). These processes are fully coupled with the simulation of vegetation dynamics and land-atmosphere exchanges of water and $\mathrm{CO}_{2}$. In common with the MC-Fire DGVM [Lenihan et al., 1998; Bachelet et al., 2001], LPJSPITFIRE relies on a comprehensive implementation of the Rothermel [1972] fire spread equations, with the vegetation dynamics calculations providing the fuel bed properties that have to be specified in operational uses of Rothermel's model. LPJ-SPITFIRE has been fully documented by Thonicke et al. [2010]. An evaluation of surface hydrology simulated by LPX is presented by Murray et al. [2011].

[10] Figure 1 summarizes the information flows in LPX, which shares the following key features of LPJ-SPITFIRE:

[11] 1. Ignitions are modeled by a deterministic approximation of a spatial Poisson process. The number of observed lightning flashes per unit area and time is multiplied by 0.030 to account for the proportion of observed flashes that reach the ground and the proportion of such flashes that has sufficient energy to start a fire [Latham and Schlieter, 1989; Latham and Williams, 2001; Rakov and Uman, 2003], yielding an expected number of "ignition events" per unit area and time.
[12] 2. The probability that an ignition event starts a fire is zero when the fuel load is below a threshold of $90 \mathrm{~g} \mathrm{C} \mathrm{m}^{-2}$. Otherwise it rises from zero, at the moisture of extinction of the fuel, to unity at complete dryness. This probability is multiplied by the grid cell area, and the expected number of ignition events per unit area and time, to give a daily number of fires.

[13] 3. Litter production and decay follow the vegetation dynamics algorithms in LPJ [Sitch et al., 2003], with additional rules for the allocation of dead carbon to four size classes of fuel (following the standard classification into $1 \mathrm{~h}$, $10 \mathrm{~h}, 100 \mathrm{~h}$ and $1000 \mathrm{~h}$ fuels) by different PFTs. The time designations refer to approximate $e$-folding times for equilibration of moisture content between fuel and air.

[14] 4. Daily precipitation is simulated based on monthly precipitation and fractional wet days using a simple weather generator [Gerten et al., 2004]. An index of litter moisture status is progressively reduced through consecutive dry days.

[15] 5. Litter drying is modeled as a first-order decay process with different rate constants for the fuel classes. The rate constants are modified by the current day's value of the Nesterov Index, estimated from mean daily maximum and minimum temperatures. The total moisture status of the $1 \mathrm{~h}$ fuel also takes account of the amount and moisture content of live fuel (foliage of herbaceous PFTs), which depends on soil moisture and therefore generally declines less rapidly than that of the fine litter fraction. A scalar representing the moisture content of the composite fuel bed is calculated, based on the $1 \mathrm{~h}, 10 \mathrm{~h}, 100 \mathrm{~h}$ fuels, for use in calculating the probability of fire starts and the rate of fire spread.

[16] 6. The rate of fire spread is determined using the Rothermel [1972] equations, ignoring topographic effects. The rate of spread depends on wind speed and the moisture content, mineral content and physical properties of the fuel. Surface area to volume ratios and packing ratios differ among fuel classes. Fuel bulk densities also differ among PFTs. 
[17] 7. The proportion of fuel consumed depends on fuel moisture status, following empirical equations which differ among the four fuel classes.

[18] 8. Fire intensity is calculated as the product of fuel heat content, proportion consumed, and rate of spread. Fires that fail to reach an intensity of $50 \mathrm{~kW} \mathrm{~m}^{-1}$ are suppressed.

[19] 9. Cambial damage and crown scorch are modeled separately, as independent causes of woody plant mortality. Cambial damage depends on fire intensity and duration in relation to bark thickness (a PFT-specific linear function of stem diameter). Crown scorch depends on flame height (a power function of fire intensity) in relation to canopy base height (a PFT-dependent proportion of total plant height).

[20] 10. Fire duration is a monotone function of burning conditions as expressed in the fire start probability. Fires are assumed to be elliptical, the ratio of long and short axes depending on wind speed (this relationship is different for woody and herbaceous PFTs, with intermediate shapes for mixtures). These assumptions allow calculation of the area burnt per fire.

[21] 11. The product of the number of fires and their area gives the daily burnt area, which is expressed as a fraction of grid cell area to yield the fractional area burnt.

[22] 12. Burnt area is assumed to be nonflammable until the following year.

[23] In contrast with LPJ-SPITFIRE, LPX accounts only for fires started by lightning. The parameterization of human ignitions in LPJ-SPITFIRE has been removed. As a result, LPX does not simulate fires in vegetation (e.g., tropical moist forests) that would not normally burn unless ignited deliberately. Nevertheless, the model is capable of simulating the main features of the fire regime, even in areas where many fires are started by humans. This apparently paradoxical ability is consistent with evidence that humanset fires in naturally fire-prone regions tend to preempt, rather than augment, the natural fire regime [e.g., Keeley and Bond, 2001]. The removal of the human ignition function greatly simplifies the evaluation of the model, and eliminates its dependence on very poorly known relationships between human ignitions and population density.

[24] LPX incorporates the following additional improvements over the corresponding process representations in LPJ-SPITFIRE:

[25] 1. The probability that an ignition event starts a fire in LPX includes a factor related to the fraction of wet days in each month:

$$
\mathrm{P}_{+}=\left(1-f_{w}\right)^{\beta}
$$

where $f_{w}$ is the wet day fraction and $\beta$ is a parameter $(0<\beta \ll 1)$. Equation (1) reduces the effectiveness of ignition events in wet months, reflecting the association of lightning strikes with wet days within any given month. The use of monthly climatologies of lightning flashes, and monthly precipitation data, means that this association is not captured in the input data. A single global value of $\beta=0.001$ was selected by trial and error as giving the best fit to the observed seasonality of burnt area for a north-south transect across the Sahel. This approach allows LPX to simulate geographic patterns in the seasonality of burning with only one tuned parameter.
[26] 2. Drying of the composite fuel bed in LPX is calculated as

$$
\omega_{o}=\Sigma_{\mathrm{i}=1,3}\left(w_{i} / w_{o}\right) \exp \left(-\alpha_{i} \mathrm{NI}\right)
$$

where $\omega_{o}$ is the litter moisture scalar, the $w_{i}$ are the masses of the $1 \mathrm{~h}, 10 \mathrm{~h}$ and $100 \mathrm{~h}$ fuels, $w_{o}=\sum_{i=1,3} w_{i}$, the $\alpha_{i}$ are rate constants (inversely proportional to the surface area to volume ratio of the fuel particles) for the three fuel classes, and NI is the current day's Nesterov Index accumulated over the period since the most recent wet day. Equation (2) treats the moisture content of the fuel as a weighted average of the moisture contents of its constituent fuel classes. This is in contrast to LPJ-SPITFIRE, where the fuel is assumed to follow a drying curve with a single rate constant derived as a weighted average of the rate constants of the three fuel classes. The new formulation is more realistic as it allows different components of the fuel to dry at different rates.

[27] 3. Decomposition of the litter in LPX is calculated daily, rather than annually. This change was found to further improve the simulation of seasonal fire timing, especially in herbaceous or shrubby vegetation with predominant fine fuels.

\subsection{Input Data}

[28] Monthly climate input data for LPX (mean daily maximum and minimum temperatures, total precipitation, and fractional sunshine hours and wet days) on a global $0.5^{\circ}$ grid were obtained from the Climatic Research Unit (CRU) TS2.1 and TS3.0 data sets (http://badc.nerc.ac.uk/browse/ badc/cru) [Mitchell and Jones, 2005; T. Mitchell, personal communication 2008]. Monthly near-surface (10 m) wind speed data from 1948 onward were obtained from the National Centers for Environmental Prediction (NCEP) reanalysis data set (NOAA-CIRES Climate Diagnostics Center, Boulder, Colorado, http://www.cdc.noaa.gov/). These data were regridded from the NCEP $1.875^{\circ}$ grid to the CRU grid using bilinear interpolation. Remotely sensed lightning flash data [see, e.g., Christian et al., 1989] were obtained from the High Resolution Monthly Climatology of lightning flashes from the Lightning Imaging Sensor-Optical Transient Detector (LIS/OTD) data set produced by H. J. Christian (http://gcmd. nasa.gov/records/GCMD_lohrmc.html) and made available by NASA. Monthly input data are converted within LPX to a pseudodaily time step by interpolation or, in the case of precipitation, using a weather generator [Gerten et al., 2004] based on monthly precipitation and the fraction of wet days each month (defined as the number of days per month with precipitation $>0.1 \mathrm{~mm}$ [New et al., 2002]) to create pseudodaily values.

[29] $\mathrm{CO}_{2}$ concentrations (one global value per year) were derived from a combination of ice core and atmospheric measurements from Mauna Loa and South Pole [Rayner et al., 2005] supplemented by data from NOAA-CMDL global averaged concentrations for the period from 1980 onward (http://www.esrl.noaa.gov/gmd/).

[30] Burnt area in each grid cell was reduced in proportion to the fractional area of croplands according to the HYDE data set [Klein Goldewijk et al., 2007], with interpolation to an annual time step from the decadal time step in HYDE. This reduction is a simple measure designed to roughly mimic the effect of intensive agriculture in reducing fuel loads. It is likely to underestimate this effect because it does 
Table 1. Summary of the Simulation Protocol ${ }^{\mathrm{a}}$

\begin{tabular}{|c|c|c|c|c|c|c|}
\hline Time Period & $\mathrm{CO}_{2}$ & $\begin{array}{c}\text { Maximum and } \\
\text { Minimum Temperature, } \\
\text { Precipitation, } \\
\text { Rain Days }\end{array}$ & Sunshine Hours & Wind Speed & Lightning & Cropland \\
\hline Spin-up & $286 \mathrm{ppm}$ & detrended CRU TS2.1 & detrended CRU TS 2.1 & detrended NCEP & climatology HRMC & 1850 HYDE crops \\
\hline $1850-1900$ & transient & detrended CRU TS2.1 & detrended CRU TS2.1 & detrended NCEP & climatology HRMC & transient HYDE crops \\
\hline 1901-1947 & transient & transientCRU TS3.0 & transient CRU TS2.1 & detrended NCEP & climatology HRMC & transient HYDE crops \\
\hline 1948-1979 & transient & transient CRU TS3.0 & transient CRU TS2.1 & transient NCEP & climatology HRMC & transient HYDE crops \\
\hline 1980-2002 & transient NOAA & transient CRU TS3.0 & transient CRU TS2.1 & transient NCEP & climatology HRMC & transient HYDE crops \\
\hline 2003-2005 & transient NOAA & transient CRU TS3.0 & $\begin{array}{l}\text { fixed at } 2002 \text { value } \\
\text { CRU TS2.1 }\end{array}$ & transient NCEP & climatology HRMC & transient HYDE crops \\
\hline
\end{tabular}

${ }^{a}$ Climatic Research Unit (CRU), National Centers for Environmental Prediction (NCEP), High Resolution Monthly Climatology (HRMC) (see text).

not consider the additional effect of landscape fragmentation on fire propagation.

\subsection{Simulation Protocol}

[31] A single LPX simulation was performed, following a sequence designed to ensure (within available data limitations, see Table 1) that simulated carbon pools do not suffer transient "shocks" and that their values for the recent observational period, during which direct atmospheric $\mathrm{CO}_{2}$ measurements and remotely sensed fire data are available, are as free as possible from artifacts propagated from earlier times.

[32] During an initial spin-up period, $\mathrm{CO}_{2}$ concentration and cropland areas were fixed at their 1850 levels. A stationary climate data set, preserving the character of the seasonal cycle and interannual climate variability, was constructed by repetition of detrended CRU and NCEP data for a recent (19482000) period. Detrending was used because the data for the observation period contain a warming signal. Repetition of these data without detrending would produce an undesirable "sawtooth" pattern in the spin-up. Detrending was performed separately for each grid cell, climate variable and month of the year, by subtracting a long-term trend estimated using locally weighted regression [Cleveland, 1993] to allow for nonlinearity. This approach is equivalent to the minimum roughness approach to smoothing nonstationary time series [Mann, 2004]. Individual curves were fitted using a smoothing window half width of 30 years, a linear local regression model, and two "robustness" iterations to downweight the influence of unusual data. The spin-up proceeded until the 50 year averages of all carbon pools were stable.

[33] The period 1851-1900 was simulated with $\mathrm{CO}_{2}$ concentration and cropland areas varying from year to year, while continuing to use the detrended CRU and NCEP data. The period 1901-1947 was simulated with $\mathrm{CO}_{2}$ concentration, cropland areas and climate (from CRU data) varying realistically from year to year, but wind speed continuing to be specified using the detrended NCEP data for 1948-2000. The period 1948-2002 was simulated with $\mathrm{CO}_{2}$ concentration, cropland areas and climate all varying according to data from year to year. The protocol for 1948-2002 was continued through 2003-2005 but with sunshine hours fixed at their 2002 values, as post-2002 values were not available. Sensitivity studies have shown that the effect of interannual variations in sunshine hours is small compared with the effects of interannual variations in temperature and precipitation, so the effect of this approximation is expected to be minor.

\subsection{Statistical Analyses}

[34] Reduced major axis (RMA) regression was used to relate anomalies (differences from the long-term mean) in simulated and "observed" (i.e., observationally based) quantities. RMA is appropriate because the "observed" quantities are partly modeled and so may also contain errors. By convention here, when comparing simulated and "observed" quantities, $y$ is simulated and $x$ is observed. Regression slopes larger or smaller than unity indicate that the simulation respectively overestimates or underestimates the amplitude of variability, while $R^{2}$ values indicate the extent of agreement between the temporal patterns regardless of amplitude.

[35] RMA regression was also used to compare fire $\mathrm{CO}_{2}$ fluxes and total $\mathrm{CO}_{2}$ fluxes. RMA is again the appropriate technique because there is no a priori reason to define one or the other variable as the predictand. By convention here, $y$ is the fire flux and $x$ is the total flux.

\section{Results}

\subsection{Amount, Pattern and Seasonal Cycles of Burnt Area}

[36] The multiyear (1997-2005) average global burnt area according to GFED3 is $3.80 \mathrm{Mm}^{2}$, or $2.8 \%$ of the total unglaciated land area. The simulated value according to LPX is somewhat less: $3.09 \mathrm{Mm}^{2}$, or $2.3 \%$. Relative to GFED3, LPX underestimates burnt area in the tropics, overestimates burnt area in some midlatitude regions and underestimates burnt area in the northern high latitudes (Figure 2).

[37] The overall extent of disagreement between GFED3 and simulated burnt area is quantified by

$$
D_{1}=\sum_{j=1, n} A_{j} \mid f_{j}(\operatorname{sim})-f_{j}(\text { obs }) \mid / \Sigma_{j=1, n} A_{j}
$$

where $\sum_{j=1, n}$ denotes summation over land grid cells (numbered from 1 to $\mathrm{n}$ ), $A_{j}$ is the area of grid cell $j$, and the $f_{j}$ are the simulated ( $\left.\mathrm{sim}\right)$ and observed (obs) multiyear average burnt area fractions for grid cell $j\left(0 \leq D_{1} \leq 1\right)$. Equation (3) represents the area-weighted average of a function for each grid cell that is the absolute value of the difference between observed and simulated fractional burnt area. The global value of $D_{1}$ obtained is $1.3 \%$ (i.e., the average error in burnt area is about half of the average burnt area). The model reproduces the main features of the geographic pattern of burnt area (Figure 2). It correctly locates the regions of maximum burnt area in the Sahel and southern Africa, southern South America, northern and 


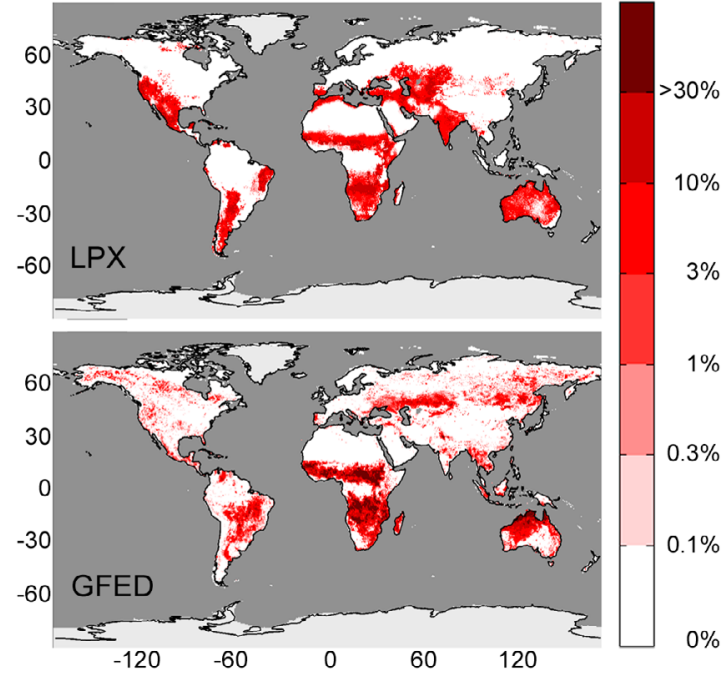

Figure 2. Annual fractional burnt area (averaged over 1997-2005) (top) as simulated by LPX and (bottom) as shown by GFED3.

interior Australia, the Mediterranean region and central Asia, and India and Southeast Asia. It underestimates burnt area in continuous forest regions, most conspicuously in the boreal zone (Alaska, northern Canada, eastern Siberia) and in some temperate forest regions including southeastern Australia, while overestimating burnt area in southwestern North America, India and the Maghreb. The model may be underestimating the effect of land use in suppressing fires in these regions. The model does not capture the substantial observed burnt area fractions in equatorial Asia, and along the southern margin of Amazonia. This shortfall is to be expected because these are the principal regions that have been subject to fire-driven deforestation, which LPX does not attempt to model.

[38] LPX reproduces well the observed spatial patterns in the average seasonal timing of the peak fire season (Figure 3). The agreement between simulated and observed fire season timing is quantified by

$$
D_{2}=\left[1-\left(\Sigma_{j=1, n} A_{j} \cos \theta_{j} / \Sigma_{j=1, n} A_{j}\right)\right] / 2
$$

where $\theta_{j}$ is the angle between vectors representing the simulated and observed mean seasonal timing (in polar coordinates) of the area burnt $\left(0 \leq D_{2} \leq 1\right)$. As both the burnt area data and model outputs are provided on a monthly basis, the mean (observed or simulated) timing for each grid cell is calculated as a weighted average (by burnt area) of the angles corresponding to each of the 12 months. The form of equation (4) ensures that the contribution of each grid cell to the final value of $D_{2}$ is zero (the minimum) if the timing is identical, one half if the timing is off by 3 months in either direction, and one (the maximum) if the timing is off by 6 months. $D_{2}$ is then the area-weighted average of these contributions from all grid cells. The global value of $D_{2}$ obtained is 0.093 , implying that the mean seasonal timings of simulated and observed burnt area on a grid cell basis differ by just over a month (36 days).

[39] The dominant pattern of fire season timing in the northern hemisphere, as mapped by Carmona-Moreno et al.
[2005] and seen in both GFED3 and LPX, is the transition between a tropical fire region with northern winter (dry) season dominance and an extratropical fire region with northern summer (warm) season dominance (Figure 3). The model also reproduces the later timing of fires in Mexico, India, Southeast Asia (toward the end of the dry season) and abrupt transition to earlier fires (beginning of the dry season) in the northernmost part of the Sahel, bordering the Sahara desert. This behavior occurs because the dominant herbaceous fuel dries more rapidly than the fuel generated by denser, woodier vegetation nearer the equator. The dominant observed and simulated pattern in the southern hemisphere is similar to that in the north (offset by 6 months), with a relatively abrupt transition from a tropical fire region with southern winter dominance to an extratropical fire region with southern summer dominance. In both hemispheres, the transition from tropical to extratropical patterns reflects the effect of precipitation seasonality (winter rainfall in Mediterranean-type climates contrasting with summer rainfall in tropical climates) reinforced by the fact that climatic conditions in high latitudes, also summer precipitation-dominated, are generally too cold to allow burning in winter. These spatial patterns appear to be a robust feature both of satellite-derived burnt area products, and of current models [Kloster et al., 2010].

\subsection{Interannual Variability in Burnt Area}

[40] Using Tropical Rainfall Measuring Mission (TRMM) data as the source of both precipitation data and fire counts, van der Werf et al. [2008b] showed that fire in the tropics and subtropics has a pronounced unimodal relationship with mean annual precipitation. The relationship is unimodal because fuel accumulation limits fire in dry climates (increasing precipitation implies higher productivity and so more fuel to burn), while fuel moisture limits fire in wet climates [van der Werf et al., 2008b; Archibald et al., 2009]. Figure 4 summarizes the observed and modeled relation-

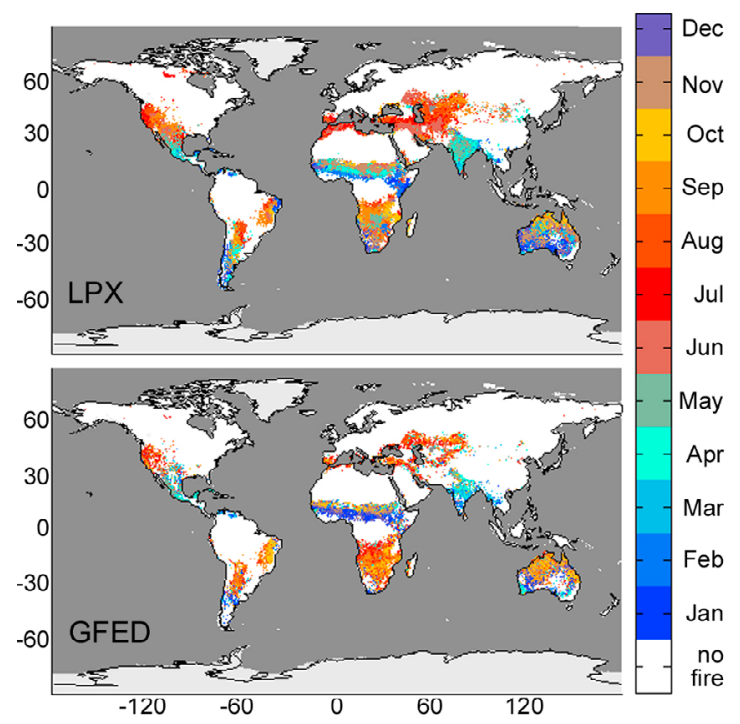

Figure 3. Month of maximum burnt area (averaged over 1997-2005 for those areas where LPX simulates $>0.1 \%$ area burnt), (top) as simulated by LPX and (bottom) as shown by GFED3. 


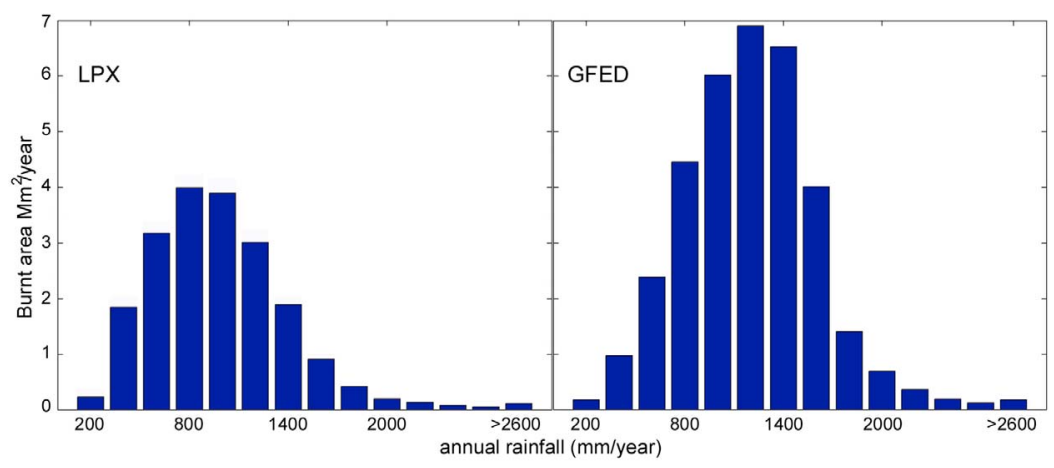

Figure 4. Fractional burnt area between $35^{\circ} \mathrm{N}$ and $35^{\circ} \mathrm{S}$, in $200 \mathrm{~mm}$ bins of mean annual precipitation, according to (left) LPX and (right) GFED3.

ships between burnt area and mean annual precipitation for the global tropical/subtropical belt, but now using GFED3 burnt area and CRU precipitation to derive the observed relationships. GFED3 and LPX show the same general pattern, with a distinct maximum of burnt area around mean annual precipitation values of $1200 \mathrm{~mm}$ (GFED3) or $900 \mathrm{~mm}$ (LPX). Overall totals are less in LPX because it does not simulate the extent of fire in the deforestation zones of the tropics (Amazonia and equatorial Asia). This bias may also explain why the modal precipitation for fire as estimated by LPX is lower than that in GFED3.

[41] The opposition of "fuel-limited" fire regimes in semiarid climates and "moisture-limited" fire regimes in wetter climates has important consequences for interannual variability. van der Werf et al. [2008b] mapped the interannual correlations between fires and an index of fire season dryness, and between fires and total precipitation in the antecedent fuel accumulation season. We show patterns that are generally similar to those demonstrated by van der Werf et al. [2008b], but now using GFED3 burnt area (instead of active fire counts) and CRU precipitation data, and we compare these with the corresponding patterns simulated by LPX. Correlations are shown for burnt area against an index $I$, which is directly proportional to van der Werf et al.'s [2008b] "fire-driven deforestation potential" (FDP):

$$
I=\sqrt{ } \Sigma_{i=1,8}^{+}\left(1-P_{i} / 100\right)
$$

where $P_{i}$ is the precipitation in month $i[\mathrm{~mm}]$ and $\Sigma^{+}$denotes summation over nonnegative values. Summation is over the current fire season, defined as the 8 month period including the 3 months before the average peak fire month and the 4 months afterward (Figure 5, top). Correlations are also shown against total precipitation over the fuel accumulation season, defined as the 13 month period up to and including the average peak fire month (Figure 5, middle). GFED3 and LPX show spatial patterns in the sign of the correlations, and some similar features. Australia, for example, shows the signature of fuel limitation in the interior (positive correlation with rainfall, negative with FDP) contrasting with moisture limitation at grid cells in the far north and again in the south. Several "hot spots" of fuel-limited fire regimes are shown in the drier regions of southern Africa, most clearly in the map of correlations with precipitation (Figure 5, middle). Fuel limitation is shown along the northern fringe of the Sahel, and toward the Horn of Africa, most clearly in the map of correlations with FDP (Figure 5, top). These similarities are encouraging, although both observations and model results for these correlations show considerable patchiness in most regions.

[42] Figure 5 (bottom) shows correlations between burnt area and the Southern Oscillation Index, SOI (http://www. bom.gov.au/climate/current//soihtm1.shtml). GFED3 and LPX show generally similar patterns in those regions where LPX simulates fires. The Sahel, eastern Brazil and parts of northern and interior Australia stand out as a regions where burnt area is
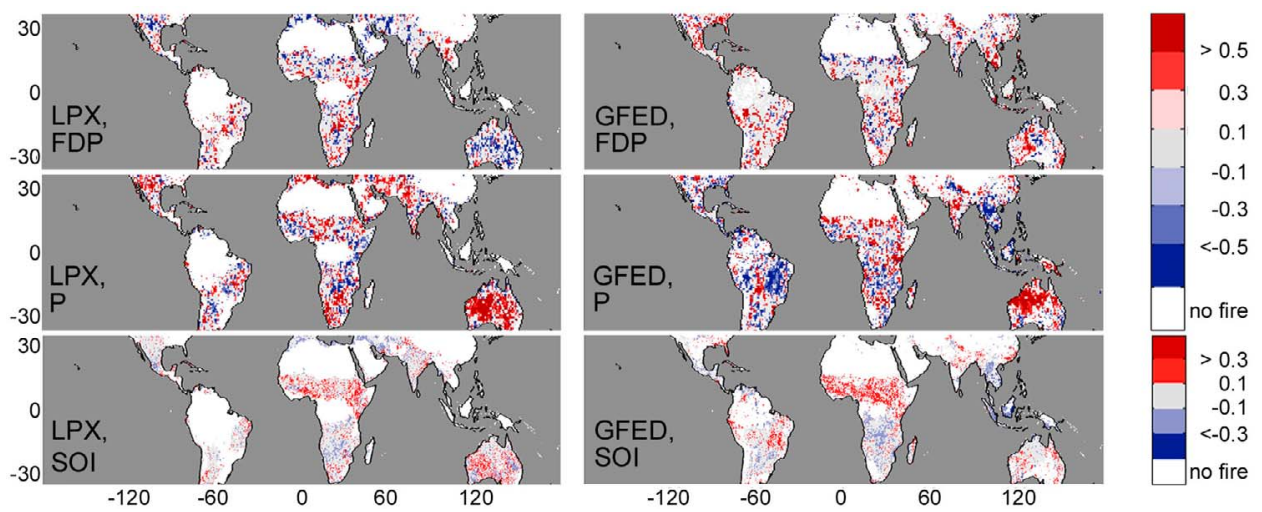

Figure 5. Interannual correlations of burnt area with (top) van der Werf et al.'s [2008b] index of firedriven deforestation potential, (middle) precipitation in the antecedent fuel accumulation season, and (bottom) the Southern Oscillation Index (SOI). Results are shown for (left) LPX and (right) GFED3. 


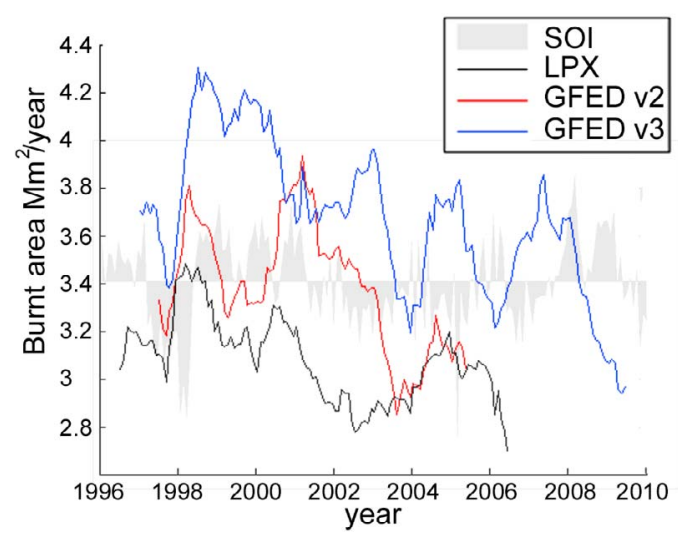

Figure 6. Twelve month running means of global burnt area $\left(\mathrm{Mm}^{2}\right)$ according to LPX, GFED2.1 and GFED3. The time series of the Southern Oscillation Index (SOI) is superimposed.

positively correlated with the SOI (i.e., burning is less in El Niño years). In southern Africa, by contrast, burning is more in El Niño years. A notable feature for GFED3 is the consistent negative correlation with SOI in Indonesia, but LPX simulates no fires there.

[43] There are both differences and common features among the GFED2.1, GFED3 and LPX time series of burnt area (Figure 6). The peak in early 1998 followed by a decline is common to all three time series, but GFED3 does not show the trough in late 1999 and the peak in mid-2000 that are common to GFED2.1 and LPX. All three time series show low values by 2004, followed by a peak in 2005 and subsequent decline. Figure 6 also shows the time series of the SOI. Burnt area peaks shown in all time series for 1998 and 2005 correspond to El Niño events (large negative excursions of the SOI) and GFED3 shows similar correspondences continuing after 2005. However, SOI does not predict all features of any of the time series.

\subsection{Variability of the Total $\mathrm{CO}_{2}$ Flux}

[44] Figure 7 (top) shows the interannual variability of the total land-atmosphere $\mathrm{CO}_{2}$ flux, calculated from atmospheric $\mathrm{CO}_{2}$ concentrations using various methods and periods, and the same quantity simulated by LPX. This quantity represents the balance of terrestrial biosphere uptake of $\mathrm{CO}_{2}$ via photosynthesis (gross primary production, GPP), and loss of $\mathrm{CO}_{2}$ in autotrophic (plant) and heterotrophic (decomposer) respiration and in fires. The gross fluxes of GPP and total respiration are very large, around $120 \mathrm{PgC} \mathrm{yr}^{-1}$. These opposing fluxes are expected to be approximately balanced, because the respiring pools must adjust on a decadal time scale so that, for example, a long-term increase in GPP would be balanced by an increase in vegetation and soil carbon and thus an increase in total respiration. On the other hand, relatively small imbalances (including fire variations) associated with interannual climate variability could have a substantial impact on the total land-atmosphere flux, as is observed [Prentice et al., 2001; Denman et al., 2007].

[45] Visual comparison of the observed and modeled total land-atmosphere $\mathrm{CO}_{2}$ flux (Figure 7) shows that the model can reproduce approximately the correct amplitude and timing of peaks and troughs of the terrestrial carbon balance. Statistical comparisons of the 12 month running means have been made for the period of overlap of all four inversions (July 1988 to July 1998), yielding $\mathrm{R}^{2}$ values of 0.64 (Bousquet), 0.63 (Rödenbeck), 0.53 (Baker) and 0.52 (LSCE), with RMA slopes of $1.14,1.09,0.96$ and 1.23, respectively, indicating that both the amplitude and pattern of total $\mathrm{CO}_{2}$ flux are well simulated within the uncertainties of the inversion methodology. Similar results are obtained when the comparison is made for annual totals based on "ENSO years" (July through June): $\mathrm{R}^{2}$ values are 0.60 (Bousquet), 0.50 (Rödenbeck), 0.35 (Baker) and 0.44 (LSCE) with RMA slopes of 1.31, $1.30,1.04$ and 1.28, respectively. The model and the inversions reproduce the well-known relationship between positive land-atmosphere $\mathrm{CO}_{2}$ flux anomalies and El Niño events.

\subsection{Amount and Variability of the Fire $\mathrm{CO}_{2}$ Flux}

[46] The global fire $\mathrm{CO}_{2}$ flux simulated by LPX, averaged over 1997-2005, is $3.81 \mathrm{Pg} \mathrm{C} \mathrm{yr}^{-1}$. This is larger than the GFED3 estimate of $2.09 \mathrm{Pg} \mathrm{C} \mathrm{yr}^{-1}$ for the same period, and also exceeds a number of published estimates for various periods that lie in the range 1.7 to $2.5 \mathrm{Pg} \mathrm{C} \mathrm{yr}^{-1}$ [e.g., Thonicke et al., 2010; Kloster et al., 2010]. It is closer to the estimate of $3.65 \mathrm{Pg} \mathrm{C} \mathrm{yr}^{-1}\left(13.4 \mathrm{Pg} \mathrm{CO}_{2} \mathrm{yr}^{-1}\right)$ for total biomass combustion by Andreae and Merlet [2001], but this estimate is not directly comparable because it includes combustion sources not considered by LPX. It is also closer to the estimate of $3.53 \mathrm{Pg} \mathrm{C} \mathrm{yr}^{-1}$ by van der Werf et al. [2004], but this value has been downgraded in later work. Thus, although LPX simulates a global burnt area smaller than GFED3, the simulated fire $\mathrm{CO}_{2}$ flux is greater than that estimated in GFED3 and a number of more recent studies, suggesting that LPX may be overestimating either aboveground biomass or combustion efficiencies in the forest ecosystems that contribute most to the global flux. There are nevertheless large uncertainties associated with all bottomup estimates of the annual mean global fire $\mathrm{CO}_{2}$ flux due to incomplete knowledge of both standing biomass and combustion efficiencies for fires in different ecosystems and weather conditions, and as yet, no established method to provide a top-down constraint on its value.

[47] Interannual variability of the fire $\mathrm{CO}_{2}$ flux is partially decoupled from interannual variability of burnt area [van der Werf et al., 2006] because a large part of the total burnt area is in vegetation with low biomass (grasslands, shrublands and savannas), whereas a disproportionate fraction of the global fire $\mathrm{CO}_{2}$ flux derives from forest fires. GFED3 estimates of the fire flux are ultimately based on observations of fire and thereby include a component due to

Figure 7. Interannual variability of the land-atmosphere $\mathrm{CO}_{2}$ flux (reduced to zero mean and detrended) from the three $\mathrm{CO}_{2}$ concentration inversions reproduced in the IPCC Fourth Assessment Report [Denman et al., 2007] and the extended LSCE inversion, compared with similarly processed interannual variability of (top) the LPX-simulated total land carbon balance and (middle) the LPX and GFED3 fire flux components of this balance. (bottom) The time series of the Southern Oscillation Index (SOI). 

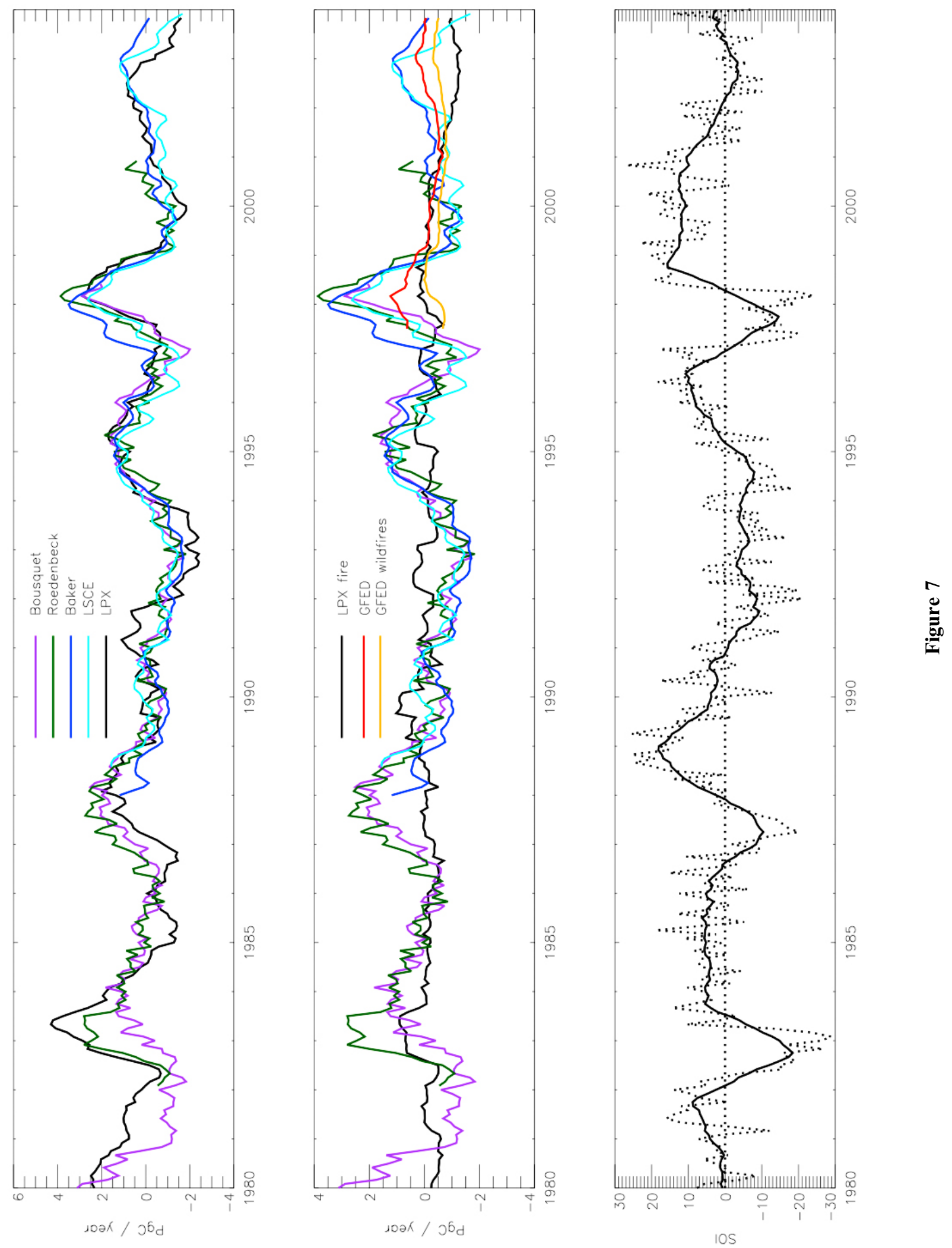
deforestation fires that is lacking in LPX. The time series of global fire $\mathrm{CO}_{2}$ flux from GFED3 (Figure 7, middle) is broadly similar to the time series of burnt area (Figure 6), but there are differences, for example, the maximum of burnt area in 2001 does not translate into a maximum in the fire $\mathrm{CO}_{2}$ flux. Simulated interannual variability in the global fire $\mathrm{CO}_{2}$ flux from LPX over the years $1997-2005$ has a similar amplitude to and is positively correlated, although weakly, with interannual variability in the global fire $\mathrm{CO}_{2}$ flux from GFED3 $\left(\mathrm{R}^{2}=0.09, y=0.90 x\right)$.

[48] Figure 7 allows comparison of simulated fire fluxes with the SOI (Figure 7, bottom), over the whole period shown for LPX, and over the more limited observation period of GFED3. In contrast with the simulated total $\mathrm{CO}_{2}$ flux, the LPX simulated fire $\mathrm{CO}_{2}$ flux is not significantly related to the SOI. Some El Niño events register as transient spikes in the LPX fire flux (e.g., 1993, 1997) but others do not. The GFED3 fire fluxes show a significant negative correlation with the SOI $\left(\mathrm{R}^{2}=0.24\right.$ based on ENSO years $)$ and display a larger peak than LPX does in association with the 1997-1998 El Niño event, and also a minor peak in association with the 2002-2003 event. The GFED3 estimated fluxes from wildfire only, also shown in Figure 7, are not significantly correlated with the SOI.

\subsection{Assessment of the Fire Contribution to Interannual Variability in the Carbon Cycle}

[49] During the period 1997-2005, comparison of GFED3 with the Baker and LSCE inversions (Figure 7) shows that variability in the GFED3 fire $\mathrm{CO}_{2}$ flux explains about $1 / 3$ of the variability in total $\mathrm{CO}_{2}$ flux (Baker: $\mathrm{R}^{2}=0.59, y=0.36 x$, LSCE: $\mathrm{R}^{2}=0.44, y=0.33 x$ ). This finding agrees with the assessment by van der Werf et al. [2006, 2008a] of the contribution of fire to the total $\mathrm{CO}_{2}$ flux anomaly during 1997-1998. A comparison over the same interval for LPX yields numerically similar RMA regression slopes, but weak or nonexistent correlations (Baker: $\mathrm{R}^{2}=0.00, y=0.41 x$, LSCE: $\mathrm{R}^{2}=0.07, y=0.38 x$ ). The statistical relationship between the GFED3 fire $\mathrm{CO}_{2}$ flux and the total $\mathrm{CO}_{2}$ flux also becomes very much weaker (Baker: $\mathrm{R}^{2}=0.22, y=$ $0.28 x$, LSCE: $\mathrm{R}^{2}=0.18, y=0.26 x$ ) if the emissions from equatorial Asia are removed from the GFED3 data set. LPX underestimates the burning "spike" shown in GFED3 during 1997-1998 and produces very little burning at all in equatorial Asia, whereas most burning as shown in GFED3 during this period is attributed to deforestation fires and peat fires taking place in equatorial Asia. The data show the dominant role of this region in determining both the relationship of recent global fire $\mathrm{CO}_{2}$ flux variability to ENSO, and the global contribution of fire variability to the terrestrial carbon balance.

\section{Discussion}

[50] Because many fires are started, accidentally or deliberately, by people, studies of the role of fire in biogeochemical cycles have often assumed that most biomass burning is anthropogenic [Seiler and Crutzen, 1980; Crutzen and Zimmermann, 1991; Ito and Penner, 2005]. This assumption implies, incorrectly, that pre-Anthropocene biomass burning must have been an order of magnitude less than today. In reality, fire has been pervasive throughout the geological record of land plants [Scott, 2009], including the late Pleistocene ice ages in Europe, with no discernible difference in fire regimes before and after the arrival of modern humans [Daniau et al., 2010a]. Fire has been continuously present since the last glacial maximum in both populated and unpopulated regions [Power et al., 2008]. Furthermore, biomass burning declined steeply in many regions coincident with the spread of European-style agriculture and grazing animals in the late 19th century [Savage and Swetnam, 1990; Mouillot and Field, 2005; Marlon et al., 2008; Pechony and Shindell, 2010] while spatially, burnt area today declines with human population density and other indicators of human footprint [Barbosa et al., 1999; Archibald et al., 2009]. The role of ignitions (whether human or natural) in present-day fire regimes is a complex topic requiring further analysis. However, there is strong evidence that fuel load and climatic conditions provide the first-order controls on burnt area [Archibald et al., 2009; Krawchuk et al., 2009]. Fires deliberately set near the climatic margin of flammability in moist tropical forests are the outstanding exception. Yet "deforestation fires," roughly estimated to account for about $1 / 5$ of the total annual fire $\mathrm{CO}_{2}$ flux [Bowman et al., 2009; van der Werf et al., 2010], are tightly constrained by climate variability, because the meteorological "windows of opportunity" for burning in these areas are short [van der Werf et al., 2008a].

[51] The data-model comparisons presented here show that the LPX DGVM can simulate key observed features of the climate-dependent (spatial and temporal) variability of wildfire regimes and the total global land-atmosphere $\mathrm{CO}_{2}$ flux, and make credible estimates of the contribution of wildfire to this flux. Model calibration was minimal: only the $\beta$ parameter in equation (1) was calibrated against data, for a single region, yet the model generated a realistic global geographic pattern of fire seasonality using this one global value. Remaining deficiencies in the model include the systematic underestimation of burnt area in temperate and boreal forests; a likely overestimation of the total global $\mathrm{CO}_{2}$ flux from fires (particularly taking into account that the model does not simulate deforestation fires); and a simplistic approach to the simulation of land use effects on fire, which may limit the model's ability to reproduce relationships of the type shown in Figure 5 as well as its accuracy in simulating burnt area in managed landscapes.

[52] The model's ability to mimic the major geographic patterns in the amount, seasonality and environmental preconditions of burning, despite neglecting human ignitions, is consistent with the idea that vegetation flammability and weather conditions (rather than ignition sources) are the firstorder controls of fire regimes; and with the growing body of paleoecological and archeological evidence that fire regimes have been sensitive to climate, while not responding to major changes in human population or culture [Marlon et al., 2008, 2009; Daniau et al., 2010a, 2010b; Harrison et al., 2010]. However, the omission of human ignitions also explains why the model fails to reproduce the observed biomass burning in moist tropical forests, and in particular it probably also explains why the model does not capture the full impact of the 1997-1998 fires on the terrestrial carbon balance. The relatively small tropical land area affected by deforestation assumes much greater importance for the fire $\mathrm{CO}_{2}$ flux than it does for burnt area, because of the high aboveground carbon 
content of moist tropical forests. The analysis of van der Werf et al. [2008a] indicates that the component of total $\mathrm{CO}_{2}$ flux variability attributable to the climate dependence of global biomass burning would be relatively small, were it not for the strong dependence of anthropogenic fires on climate. Some of the differences in the time series of fire $\mathrm{CO}_{2}$ fluxes from LPX and GFED3 may be attributed to the fact that the latter includes large fluxes from fires in equatorial Asia (and to a lesser extent Amazonia) that are believed to represent mainly opportunistic burning [Cochrane and Laurance, 2002; Fearnside, 2005; Page et al., 2009].

[53] Numerous studies from Bacastow [1976] onward have pointed out the close link between interannual variability of the $\mathrm{CO}_{2}$ growth rate and ENSO, with positive anomalies (i.e., reduced $\mathrm{CO}_{2}$ uptake from the atmosphere) corresponding to El Niño events [e.g., Jones et al., 2001; Prentice et al., 2001; Denman et al., 2007]. This link is attributed to the response of the terrestrial biosphere to temperature variations. The striking exception to the pattern due to the Pinatubo eruption in 1991 [Lucht et al., 2002; Mercado et al., 2009] is also well established. The global environmental effects of the eruption more than canceled out the expected effect of the El Niño that occurred around the same time, producing a marked reduction in the observed atmospheric $\mathrm{CO}_{2}$ growth rate during 19911992. These features are clear in the inversions, and in the LPX simulations, as shown in Figure 7.

[54] Comparison of GFED3 time series of global burnt area (Figure 6) and fire $\mathrm{CO}_{2}$ flux (Figure 7) with the SOI, however, shows weaker correspondences. A number of studies published in the years following the strong 1997-1998 El Niño event [e.g., Langenfelds et al., 2002; Page et al., 2002; van der Werf et al., 2004] drew attention to the combination of positive anomalies in both the total land-atmosphere $\mathrm{CO}_{2}$ flux and multiple indicators of biomass burning, linked in time to the El Niño, and the decline of both features as it subsided. The analysis of Carmona-Moreno et al. [2005], using Advanced Very High Resolution Radiometer data to examine fire probability variations semiquantitatively from the early 1980s onward, showed a marked equatorward extension of tropical fires during the two strong El Niño events of 1982-1983 and 1997-1998. These findings have encouraged a perception that fire variability linked to ENSO is a (perhaps the) major determinant of interannual variability in the land-atmosphere $\mathrm{CO}_{2}$ flux. However, in so far as the GFED3 fire $\mathrm{CO}_{2}$ fluxes can be taken as reliable: (1) fire $\mathrm{CO}_{2}$ flux variations (including deforestation fires) do not account for most of the interannual variations in the total $\mathrm{CO}_{2}$ flux; and (2) the SOI is not a strong predictor of the fire $\mathrm{CO}_{2}$ flux. The GFED3 data further suggest that the observed relationship between the global fire $\mathrm{CO}_{2}$ flux and the SOI depends mainly on the large carbon releases from deforestation fires that are possible (thanks to unusually good burning conditions) during the strongest El Niño events. In a broader global context, given that the sign of the relationship between the SOI and burnt area varies among regions as shown by both GFED3 and LPX (Figure 5, bottom), so must the sign of the relationship between the SOI and fire $\mathrm{CO}_{2}$ flux. As there is considerable geographic variation in the climatic signature of different ENSO events, it follows that there must be variation in the net global fire $\mathrm{CO}_{2}$ flux that cannot be predicted accurately by a single ENSO index.
[55] Fire is a part of natural ecosystem dynamics, yet fraught with dangers for human activities. Large wildfires are increasing in some regions [Cary, 2002; Kajii et al., 2002; Gillett et al., 2004; Running, 2006; Westerling et al., 2006; Balzter et al., 2007; Groisman et al., 2007] and probably set to increase further as a consequence of climate change [Scholze et al., 2006; Lavorel et al., 2007; Girardin and Mudelsee, 2008; Balshi et al., 2009; Krawchuk et al., 2009; Pechony and Shindell, 2010]. Our analysis indicates that the relationships between fire, carbon cycling and climate are complex, but not intractable. We have shown that quite subtle global patterns revealed by statistical analysis of remote sensing data can be mimicked in a DGVM. Simple, monotonic relationships between, for example, precipitation and fire, fire and ENSO, or fire and human population, are contradicted both by analysis of remotely sensed data and by modeling. Process-based modeling is the key to developing the predictive ability needed to assess future perspectives for fire risks and their mitigation; further work is needed to improve representation of the consequences of land use, landuse change and fire management.

[56] Acknowledgments. Research supported by the European Union Sixth Framework Programme project Hydrogen, Methane, Nitrous Oxide (HYMN), the UK Natural Environment Research Council (NERC) project ACACIA, and the NERC program Quantifying and Understanding the Earth System (QUEST) core team contract. We thank Guido van der Werf for discussions, Lei Lei Dong and Yan Zhao for technical assistance, and Fréderic Chevalier for providing the LSCE inversion fluxes.

\section{References}

Andreae, M. O., and P. Merlet (2001), Emission of trace gases and aerosols from biomass burning, Global Biogeochem. Cycles, 15, 955-966, doi:10.1029/2000GB001382.

Archibald, S., D. P. Roy, B. W. van Wilgen, and R. J. Scholes (2009), What limits fire? An examination of drivers of burnt area in southern Africa, Global Change Biol., 15(3), 613-630, doi:10.1111/j.1365-2486.2008. 01754.x.

Arora, V. K., and G. J. Boer (2005), Fire as an interactive component of dynamic vegetation models, J. Geophys. Res., 110, G02008, doi:10.1029/ 2005JG000042.

Bacastow, R. B. (1976), Modulation of atmospheric carbon cycle by the Southern Oscillation, Nature, 261, 116-118, doi:10.1038/261116a0.

Bachelet, D., J. M. Lenihan, C. Daly, R. P. Neilson, D. S. Ojima, and W. J. Parton (2001), MC1: A dynamic vegetation model for estimating the distribution of vegetation and associated ecosystem fluxes of carbon, nutrients and water, Gen. Tech. Rep. PNW-GTR-508, 95 pp., U.S. Dep. of Agric., For. Serv., Pac. Northwest Res. Stn., Portland, Oreg.

Baker, D. F., S. C. Doney, and D. S. Schimel (2006), Variational data assimilation for atmospheric $\mathrm{CO}_{2}$, Tellus, Ser. B, 58(5), 359-365, doi:10.1111 j.1600-0889.2006.00218.x.

Balshi, M. S., A. D. McGuire, P. Duffy, M. Flannigan, D. W. Kicklighter, and J. Melillo (2009), Vulnerability of carbon storage in North American boreal forests to wildfires during the 21 st century, Global Change Biol., 15, 1491-1510, doi:10.1111/j.1365-2486.2009.01877.x.

Balzter, H., F. Gerard, G. Weedon, W. Grey, B. Combal, E. Bartholome, S. Bartalev, and S. Los (2007), Coupling of vegetation growing season anomalies with hemispheric and regional scale climate patterns in Central and East Siberia, J. Clim., 20, 3713-3729, doi:10.1175/JCLI4226.

Barbosa, P. M., D. Stroppiana, J.-M. Gregoire, and J. M. C. Pereira (1999), An assessment of vegetation fire in Africa (1981-1991), Burned areas, burned biomass, and atmospheric emissions, Global Biogeochem. Cycles, 13, 933-950, doi:10.1029/1999GB900042.

Bousquet, P., P. Peylin, P. Ciais, C. Le Quéré, P. Friedlingstein, and P. P. Tans (2000), Regional changes in carbon dioxide fluxes of land and oceans since 1980, Science, 290, 1342-1346, doi:10.1126/science.290.5495.1342. Bousquet, P., et al. (2006), Contribution of anthropogenic and natural sources to atmospheric methane variability, Nature, 443, 439-443, doi:10.1038/nature 05132 .

Bowman, D. M. J. S., et al. (2009), Fire in the Earth system, Science, 324, 481-484, doi:10.1126/science. 1163886. 
Carmona-Moreno, C., A. Belward, J.-P. Malingreau, A. Hartley, M. GarciaAlegre, M. Antonovskiy, V. Buchstaber, and V. Pivovarov (2005), Characterizing interannual variations in global fire calendar using data from Earth observing satellites, Global Change Biol., 11, 1537-1555, doi:10.1111/ j.1365-2486.2005.01003.x.

Cary, G. (2002), Importance of a changing climate for fire regimes in Australia in Flammable Australia: The Fire Regimes and Biodiversity of a Continent, edited by R. Bradstock et al., pp. 26-46, Cambridge Univ. Press, Cambridge, U. K.

Chevallier, F., et al. (2010), $\mathrm{CO}_{2}$ surface fluxes at grid point scale estimated from a global 21 year reanalysis of atmospheric measurements, J. Geophys. Res., 115, D21307, doi:10.1029/2010JD013887.

Christian, H. J., R. J. Blakeslee, and S. J. Goodman (1989), The detection of lightning from geostationary orbit, J. Geophys. Res., 94, 13,329-13,337, doi:10.1029/JD094iD11p13329.

Cleveland, W. S. (1993), Visualizing Data, Hobart Press, Summit, N. J.

Cochrane, M. A., and W. F. Laurance (2002), Fire as a large-scale edge effect in Amazonian forests, J. Trop. Ecol., 18, 311-325, doi:10.1017/ S0266467402002237.

Cox, P. M., R. A. Betts, C. D. Jones, S. A. Spall, and I. J. Totterdell (2000), Acceleration of global warming due to carbon-cycle feedbacks in a coupled climate model, Nature, 408, 184-187, doi:10.1038/35041539.

Crutzen, P. J., and P. H. Zimmermann (1991), The changing photochemistry of the troposphere, Tellus, 43, 136-151.

Daniau, A. L., F. d'Errico, and M. F. Sánchez Goñi (2010a), Testing the hypothesis of fire use for ecosystem management by Neanderthal and Upper Palaeolithic Modern Human populations, PLoS ONE, 5(2), e9157, doi:10.1371/journal.pone.0009157.

Daniau, A.-L., S. P. Harrison, and P. J. Bartlein (2010b), Fire regimes during the last glacial, Quat. Sci. Rev., 29, 2918-2930, doi:10.1016/j.quascirev. 2009.11.008

Denman, K. L., et al. (2007), Couplings between changes in the climate system and biogeochemistry, in Climate Change 2007: The Physical Science Basis. Contribution of Working Group I to the Fourth Assessment Report of the Intergovernmental Panel on Climate Change, edited by S. Solomon et al., pp. 499-587, Cambridge Univ. Press, Cambridge.

Fearnside, P. M. (2005), Deforestation in Brazilian Amazonia: History, rates, and consequences, Conserv. Biol., 19, 680-688, doi:10.1111/j.15231739.2005.00697.x

Friedlingstein, P., et al. (2006), Climate-carbon cycle feedback analysis: Results from the $\mathrm{C}^{4} \mathrm{MIP}$ model intercomparison, J. Clim., 19, 3337-3353, doi:10.1175/JCLI3800.1

Gerten, D., S. Schaphoff, U. Haberlandt, W. Lucht, and S. Sitch (2004), Terrestrial vegetation and water balance-Hydrological evaluation of a dynamic global vegetation model, J. Hydrol., 286, 249-270, doi:10.1016/j.jhydrol.2003.09.029.

Giglio, L., J. T. Randerson, G. R. van der Werf, P. S. Kahsibhatla, G. J. Collatz, D. C. Morton, and R. S. DeFries (2010), Assessing variability and long-term trends in burned area by merging multiple satellite fire products, Biogeosciences, 7, 1171-1186, doi:10.5194/bg-7-1171-2010.

Gillett, N. P., A. J. Weaver, F. W. Zwiers, and M. D. Flannigan (2004), Detecting the effect of climate change on Canadian forest fires, Geophys. Res. Lett., 31, L18211, doi:10.1029/2004GL020876.

Girardin, M. P., and M. Mudelsee (2008), Past and future changes in Canadian boreal wildfire activity, Ecol. Appl., 18, 391-406, doi:10.1890/07-0747.1.

Groisman, P. Y., et al. (2007), Potential forest fire danger over northern Eurasia: Changes during the 20th century, Global Planet. Change, 56, 371-386, doi:10.1016/j.gloplacha.2006.07.029.

Gurney, K. R., et al. (2002), Towards robust regional estimates of $\mathrm{CO}_{2}$ sources and sinks using atmospheric transport models, Nature, 415, 626-630, doi:10.1038/415626a

Harrison, S. P., J. Marlon, and P. J. Bartlein (2010), Fire in the Earth system, in Changing Climates, Earth Systems and Society, edited by J. Dodson, pp. 21-48, Springer, New York, doi:10.1007/978-90-481-8716-4_3.

Ito, A., and J. E. Penner (2005), Historical emissions of carbonaceous aerosols from biomass and fossil fuel burning for the period 1870-2000, Global Biogeochem. Cycles, 19, GB2028, doi:10.1029/2004GB002374.

Jones, C. D., M. Collins, P. M. Cox, and S. A. Spall (2001), The carbon cycle response to ENSO: A coupled climate-carbon cycle model study, J. Clim., 14, 4113-4129, doi:10.1175/1520-0442(2001)014<4113: TCCRTE $>2.0 . \mathrm{CO} ; 2$

Kajii, Y., et al. (2002), Boreal forest fires in Siberia in 1998: Estimation of area burned and emissions of pollutants by advanced very high resolution radiometer satellite data, J. Geophys. Res., 107(D24), 4745, doi:10.1029/ 2001JD001078

Keeley, J. E., and W. J. Bond (2001), On incorporating fire into our thinking about natural ecosystems: A response to Saha and Howe, Am. Nat., 158, 664-670, doi:10.1086/323594.
Klein Goldewijk, K., G. van Drecht, and A. Bouwman (2007), Mapping contemporary global cropland and grassland distributions on a $5 \times 5$ minute resolution, J. Land Use Sci., 2(3), 167-190, doi:10.1080/17474230701622940.

Kloster, S., N. M. Mahowald, J. T. Randerson, P. E. Thornton, F. M. Hoffman, S. Levis, P. J. Lawrence, J. J. Feddema, K. W. Oleson, and D. M. Lawrence (2010), Fire dynamics during the 20th century simulated by the Community Land Model, Biogeosciences, 7, 1877-1902, doi:10.5194/bg-7-1877-2010.

Krawchuk, M., M. Moritz, M.-A. Parisien, J. Van Dorn, and K. Hayhoe (2009), Global pyrogeography: The current and future distribution of wildfire, PLoS ONE, 4, e5102, doi:10.1371/journal.pone.0005102.

Kurz, W. A., and M. J. Apps (1999), A 70-year retrospective analysis of carbon fluxes in the Canadian forest sector, Ecol. Appl., 9, 526-547, doi:10.1890/1051-0761(1999)009[0526:AYRAOC]2.0.CO;2.

Langenfelds, R. L., R. J. Francey, B. C. Pak, L. P. Steele, J. Lloyd, C. M. Trudinger, and C. E. Allison (2002), Interannual growth rate variations of atmospheric $\mathrm{CO}_{2}$ and its $\delta^{13} \mathrm{C}, \mathrm{H}_{2}, \mathrm{CH}_{4}$, and $\mathrm{CO}$ between 1992 and 1999 linked to biomass burning, Global Biogeochem. Cycles, 16(3), 1048, doi:10.1029/2001GB001466.

Latham, D. J., and J. A. Schlieter (1989), Ignition probabilities of wildland fuels based on simulated lightning discharges, Res. Pap. INT-411, Intermt Res. Stn., Ogden, Utah.

Latham, D., and E. Williams (2001), Lightning and forest fires, in Forest Fires: Behavior and Ecological Effects, edited by E. A. Johnson and K. Miyanishi, pp. 376-418, Academic, San Diego, Calif.

Lavorel, S. L., M. D. Flannigan, E. F. Lambin, and M. C. Scholes (2007), Vulnerability of land systems to fire: Interactions among humans, climate, the atmosphere, and ecosystems, Mitigation Adapt. Strategies Global Change, 12, 33-53, doi:10.1007/s11027-006-9046-5.

Lenihan, J. M., C. Daly, D. Bachelet, and R. P. Neilson (1998), Simulating broad-scale fire severity in a dynamic global vegetation model, Northwest Sci., 72, 91-103.

Lucht, W., I. C. Prentice, R. B. Myneni, S. Sitch, P. Friedlingstein, W. Cramer, P. Bousquet, W. Buermann, and B. Smith (2002), Climatic control of the high-latitude vegetation greening trend and Pinatubo effect, Science, 296, 1687-1689, doi:10.1126/science. 1071828 .

Mann, M. (2004), On smoothing potentially non-stationary climate time series, Geophys. Res. Lett., 31, L07214, doi:10.1029/2004GL019569.

Marlon, J. R., C. Carcaillet, D. G. Gavin, S. P. Harrison, P. E. Higuera F. Joos, M. J. Power, and I. C. Prentice (2008), A climate-driven decline in global biomass burning during the past two millennia, Nat. Geosci., 1 , 697-702, doi:10.1038/ngeo313.

Marlon, J. R., et al. (2009), Wildfire responses to abrupt climate change in North America, Proc. Natl. Acad. Sci. U. S. A., 106(8), 2519-2524, doi:10.1073/pnas.0808212106.

McGuire, A. D., et al. (2001), Carbon balance of the terrestrial biosphere in the twentieth century: Analyses of $\mathrm{CO}_{2}$, climate and land-use effects with four process-based ecosystem models, Global Biogeochem. Cycles, 15, 183-206, doi:10.1029/2000GB001298.

Mercado, L. M., N. Bellouin, S. Sitch, O. Boucher, C. Huntingford, M. Wild, and P. M. Cox (2009), Impact of changes in diffuse radiation on the global land carbon sink, Nature, 458, 1014-1017, doi:10.1038/nature07949.

Mitchell, T., and C. D. Jones (2005), An improved method of constructing a database of monthly climate observations and associated high-resolution grid, Int. J. Climatol., 25, 693-712, doi:10.1002/joc.1181.

Mouillot, F., and C. B. Field (2005), Fire history and the global carbon budget: A $1^{\circ} \times 1^{\circ}$ fire history reconstruction for the 20th century, Global Change Biol., 11, 398-420, doi:10.1111/j.1365-2486.2005.00920.x.

Murray, S. J., P. N. Foster, and I. C. Prentice (2011), Evaluation of global continental hydrology as simulated by the Land-surface Processes and eXchanges dynamic global vegetation model, Hydrol. Earth Syst. Sci., 15, 91-105, doi:10.5194/hess-15-91-2011.

Nevison, C. D., N. M. Mahowald, S. C. Doney, I. D. Lima, G. R. van der Werf, J. T. Randerson, D. F. Baker, P. Kasibhatla, and G. A. McKinley (2008), Contribution of ocean, fossil fuel, land biosphere, and biomass burning carbon fluxes to seasonal and interannual variability in atmospheric $\mathrm{CO}_{2}$, J. Geophys. Res., 113, G01010, doi:10.1029/2007JG000408.

New, M., D. Lister, M. Hulme, and I. Makin (2002), A high-resolution data set of surface climate over global land areas, Clim. Res., 21, 1-25, doi:10.3354/cr021001.

Page, S. E., F. Siegert, J. O. Rieley, H.-D. V. Boehm, A. Jaya, and S. Limin (2002), The amount of carbon released from peat and forest fires in Indonesia during 1997, Nature, 420, 61-65, doi:10.1038/nature01131.

Page, S., A. Hoscilo, A. Langner, K. Tansey, F. Siegert, S. Limin, and J. Rieley (2009), Tropical peatland fires in Southeast Asia, in Tropical Fire Ecology: Climate Change, Land Use, and Ecosystem Dynamics, edited by M. Cochrane, pp. 263-287, Praxis, Chichester, U. K.

Patra, P. K., M. Ishizawa, S. Maksyutov, T. Nakazawa, and G. Inoue (2005), Role of biomass burning and climate anomalies for land-atmosphere car- 
bon fluxes based on inverse modeling of atmospheric $\mathrm{CO}_{2}$, Global Biogeochem. Cycles, 19, GB3005, doi:10.1029/2004GB002258.

Pechony, O., and D. T. Shindell (2009), Fire parameterization on a global scale, J. Geophys. Res., 114, D16115, doi:10.1029/2009JD011927.

Pechony, O., and D. T. Shindell (2010), Driving forces of global wildfires over the past millennium and the forthcoming century, Proc. Natl. Acad. Sci. U. S. A., doi:10.1073/pnas. 1003669107.

Peylin, P., P. Bousquet, C. Le Quéré, S. Sitch, P. Friedlingstein, G. McKinley, N. Gruber, P. Rayner, and P. Ciais (2005), Multiple constraints on regional $\mathrm{CO}_{2}$ flux variations over land and oceans, Global Biogeochem. Cycles, 19, GB1011, doi:10.1029/2003GB002214.

Power, M. J., et al. (2008), Changes in fire activity since the LGM: An assessment based on a global synthesis and analysis of charcoal data, Clim. Dyn., 30, 887-907, doi:10.1007/s00382-007-0334-x.

Prentice, I. C., G. D. Farquhar, M. J. R. Fasham, M. L. Goulden, M. Heimann, V. J. Jaramillo, H. S. Kheshgi, C. Le Quéré, R. J. Scholes, and D. W. R. Wallace (2001), The carbon cycle and atmospheric carbon dioxide, in Climate Change 2001: The Scientific Basis. Contribution of Working Group to the Third Assessment Report of the Intergovernmental Panel on Climate Change, edited by J. T. Houghton et al., pp. 183-237, Cambridge Univ. Press, Cambridge, U. K.

Rakov, V. A., and M. A. Uman (2003), Lightning: Physics and effects, 3rd ed., Cambridge Univ. Press, Cambridge, U. K

Randerson, J. T., G. R. van der Werf, G. J. Collatz, L. Giglio, C. J. Still, P. Kasibhatla, J. B. Miller, J. W. C. White, R. S. DeFries, and E. S Kasischke (2005), Fire emissions from $\mathrm{C}_{3}$ and $\mathrm{C}_{4}$ vegetation and their influence on interannual variability of atmospheric $\mathrm{CO}_{2}$ and $\delta^{13} \mathrm{CO}_{2}$, Global Biogeochem. Cycles, 19, GB2019, doi:10.1029/2004GB002366.

Rayner, P. J., M. Scholze, W. Knorr, T. Kaminski, R. Giering, and H. Widmann (2005), Two decades of terrestrial carbon fluxes from a carbon cycle data assimilation system (CCDAS), Global Biogeochem. Cycles, 19, GB2026, doi:10.1029/2004GB002254.

Rödenbeck, C., S. Houweling, M. Gloor, and M. Heimann (2003), $\mathrm{CO}_{2}$ flux history 1982-2001 inferred from atmospheric data using a global inversion of atmospheric transport, Atmos. Chem. Phys., 3, 1919-1964, doi:10.5194/acp-3-1919-2003

Rothermel, R. C. (1972), A mathematical model for predicting fire spread in wildland fuels, Gen. Tech. Rep. INT-115, U.S. Dep. of Agric., For. Serv., Intermt. For. and Range Exp. Stn., Ogden, Utah.

Running, S. W. (2006), Is global warming causing more, larger wildfires?, Science, 313, 927-928, doi:10.1126/science.1130370.

Savage, M., and T. W. Swetnam (1990), Early and persistent fire decline in a Navajo ponderosa pine forest, Ecology, 71, 2374-2378, doi:10.2307/ 1938649.

Schimel, D., and D. Baker (2002), Carbon cycle: The wildfire factor, Nature, 420, 29-30, doi:10.1038/420029a.

Scholze, M., W. Knorr, N. W. Arnell, and I. C. Prentice (2006), A climatechange risk analysis for world ecosystems, Proc. Natl. Acad. Sci. U. S. A., 103, 13,116-13,120, doi:10.1073/pnas.0601816103.

Scott, A. C. (2009), Forest fire in the fossil record, in Fire Effects on Soils and Restoration Strategies, edited by A. Cerdà and P. Robichaud, pp. 1-37, Sci. Publ., Enfield, N. H., doi:10.1201/9781439843338-c1.
Seiler, W., and P. J. Crutzen (1980), Estimates of gross and net fluxes of carbon between the biosphere and the atmosphere from biomass burning, Clim. Change, 2, 207-247, doi:10.1007/BF00137988

Sitch, S., et al. (2003), Evaluation of ecosystem dynamics, plant geography and terrestrial carbon cycling in the LPJ dynamic global vegetation model, Global Change Biol., 9, 161-185, doi:10.1046/j.1365-2486.2003.00569.x.

Thonicke, K., S. Venevsky, S. Sitch, and W. Cramer (2001), The role of fire disturbance for global vegetation dynamics: Coupling fire into a dynamic global vegetation model, Global Ecol. Biogeogr., 10, 661-677, doi:10.1046/j.1466-822X.2001.00175.x.

Thonicke, K., A. Spessa, I. C. Prentice, S. P. Harrison, L. Dong, and C. Carmona-Moreno (2010), The influence of vegetation, fire spread and fire behaviour on global biomass burning and trace gas emissions: Results from a process-based model, Biogeosciences, 7, 1991-2011, doi:10.5194/ bg-7-1991-2010.

van der Werf, G. R., J. T. Randerson, G. J. Collatz, L. Giglio, P. S. Kasibhatla, A. F. Arellano, S. C. Olsen, and E. S. Kasischke (2004), Continental-scale partitioning of fire emissions during the 1997 to 2001 El Niño/La Niña period, Science, 303, 73-76, doi:10.1126/science.1090753.

van der Werf, G. R., J. T. Randerson, L. Giglio, G. J. Collatz, P. S. Khasibatla, and A. F. Arellano Jr. (2006), Interannual variability in global biomass burning emissions from 1997 to 2004, Atmos. Chem. Phys., 6, 3423-3441, doi:10.5194/acp-6-3423-2006.

van der Werf, G. R., et al. (2008a), Climatic regulation of fire emissions and deforestation in equatorial Asia, Proc. Natl. Acad. Sci. U. S. A., 105(51), 20,350-20,355, doi:10.1073/pnas.0803375105.

van der Werf, G. R., J. T. Randerson, L. Giglio, N. Gobron, and A. J. Dolman (2008b), Climate controls on the variability of fires in the tropics and subtropics, Global Biogeochem. Cycles, 22, GB3028, doi:10.1029/2007GB003122.

van der Werf, G. R., J. T. Randerson, L. Giglio, G. J. Collatz, M. Mu, P. S. Kasibhatla, D. C. Morton, R. S. DeFries, Y. Jin, and T. T. van Leeuwen (2010), Global fire emissions and the contribution of deforestation, savanna, forest, agricultural, and peat fires (1997-2009), Atmos. Chem. Phys. Discuss., 10, 16,153-16,230, doi:10.5194/acpd-10-16153-2010.

Westerling, A. L., H. G. Hidalgo, D. R. Cayan, and T. W. Swetnam (2006), Warming and earlier spring increase western US forest wildfire activity, Science, 313, 940-943, doi:10.1126/science.1128834.

P. J. Bartlein, Department of Geography, University of Oregon, Eugene, OR 97403-1251, USA.

P. N. Foster, QUEST, Department of Earth Sciences, University of Bristol, Wills Memorial Building, Queens Road, Bristol BS8 1RJ, UK.

P. Friedlingstein, Department of Engineering, Computing and Mathematics, Harrison Building, Streatham Campus, University of Exeter, North Park Road, Exeter EX4 4QF, UK

S. P. Harrison, D. I. Kelley, and I. C. Prentice, Department of Biological Sciences, Macquarie University, North Ryde, NSW 2109, Australia. (colin. prentice@mq.edu.au) 